М.М. Дєнєжкін

Центральний науково-дослідний інститут Збройних Сил України, Київ

\title{
ШЛЯХИ ВИРІШЕННЯ ПРОБЛЕМНИХ ПИТАНЬ ПЛАНУВАННЯ РОЗВИТКУ СПРОМОЖНОСТЕЙ ВІЙСЬКОВИХ ФОРМУВАНЬ ЗБРОЙНИХ СИЛ УКРАЇНИ
}

У статті на основі результатів аналізу керівних документів, що регламентують переведення системи оборонного планування на планування розвитку Збройних Сил Украӥни (ЗС Украӥни) на основі спроможностей, отриманого досвіду переходу від планування розвитку бойових можливостей, бойового складу та його організаційної структури до планування розвитку їх спроможностей визначені проблемні питання такого переходу. Зроблено висновок про неефективність обраних стратегій такого переходу, недостатність зусиль для здійснення методичного супроводження процесу, його організаиії, якості отриманих результатів. Запропоновано можливі шляхи вирішення проблемних питань, щзо виникли в ході переходу на планування розвитку спроможностей військових формувань ЗС Украӥни. Визначено, щуо обрані стратегії використання готової системи планування розвитку спроможностей однієї з країн-членів НАТО, використання фрагментів (окремих процедур) планування спроможностей НАТО для розвитку військових формувань ЗС Украӥни не є ефективними та не можуть на сьогодні вирішити завдання такого переходу. На основі аналізу позитивних та негативних рис, можливих наслідків з урахуванням умов України запропонована стратегія, яка інтегрує в собі обидва методи планування розвитку спроможностей військових формувань в НАТО та розвитку бойових можливостей військових формувань ЗС Украӥни, включає кращчі процедури ијього процесу, щчо використовують країни-члени НАТО, враховує умови і набутий досвід планування ЗС Украӥни. Виділені можливі прочедури для взаємної інтеграції, на яких доиільно здійснити синтез двох систем планування у єдину для забезпечення ї̈ працездатності в умовах ведення бойових дій Украӥною та обмеженого часу.

Ключові слова: боєздатність, спроможність, норматив, стандарт, типові завдання, умови виконання типових завдань.

\section{Вступ}

Актуальність проблеми та її зв'язок із важливими науковими та практичними завданнями. Перехід від планування розвитку бойових можливостей до розвитку спроможностей військових формувань у Збройних Силах України (ЗС України) триває більше 10 років.

На сьогодні не можна із впевненістю зробити висновок, що напрям реалізації воєнної політики України щодо розвитку спроможностей сил оборони реалізований повною мірою. Це викликає необхідність визначити шляхи вирішення проблемних питань на основі їх аналізу для реалізації цього напряму воєнної політики.

Аналіз останніх досліджень і публікацій. Аналіз документів, що регламентують планування розвитку спроможностей ЗС України [1-11], показує їх невідповідність один одному, незавершеність та суперечливість основних положень (методології) планування на основі спроможностей НАТО [1516], відсутність дієвого, працездатного і зрозумілого методичного апарату для оцінювання спроможностей, мінімально необхідного, але достатнього переліку планувальних документів.
Незавершеність викликана наявними проблемними питаннями, які затягують процес переходу на планування розвитку спроможностей військових формувань ЗС України. Це потребує проведення аналізу існуючих проблемних питань та визначення шляхів їх вирішення.

Формулювання мети статті. Метою статті є визначення шляхів вирішення проблемних питань переходу на планування розвитку спроможностей військових формувань ЗС України.

\section{Виклад основного матеріалу}

Кількісно-якісні зміни елементів складу та їх комбінація в організаційних структурах військових формувань служать для набуття їх здатності до виконання поставлених завдань, що задовольняють вимогам до них у визначених умовах [5; 13-14].

Формально, розвиток військового формування $€$ процесом усунення або мінімізації невідповідності наявного складу і організаційної структури вимогам до них через зміни показників тактико-технічних характеристик (ТТX) зразків озброєння і військової техніки (інших носіїв спроможностей), а також комбінації цих зразків в організаційній структурі (рис. 1). 


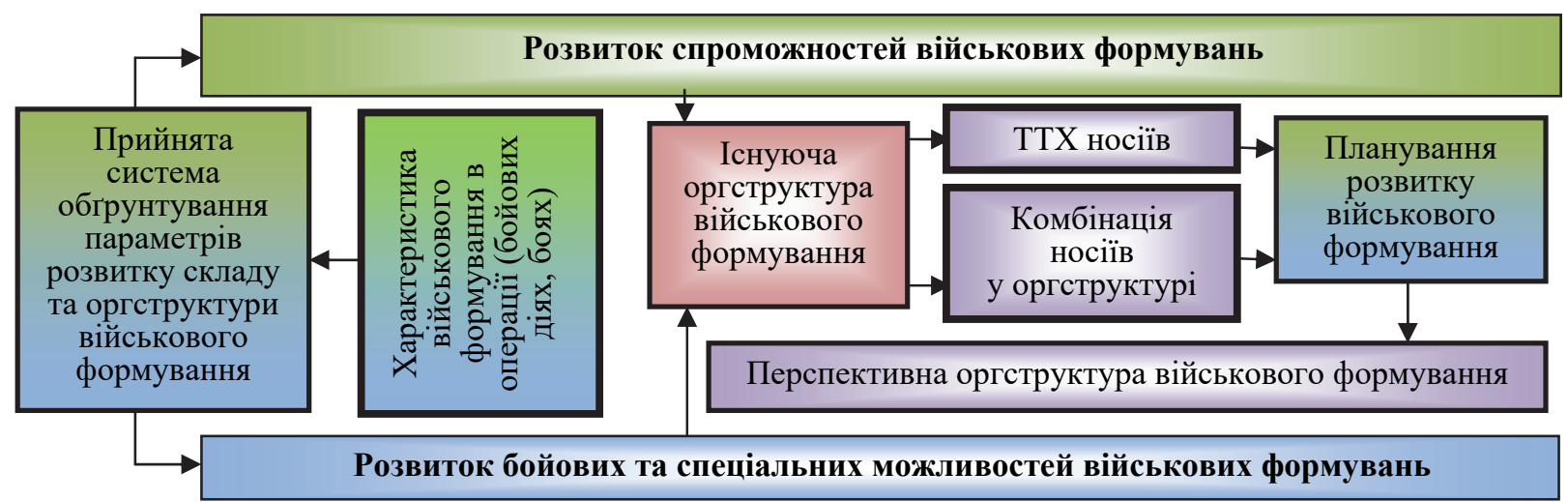

Рис. 1. Схематичне зображення двох методів обгрунтування змін характеристик військового формування Джерело: [13].

Обгрунтування характеристик кількісноякісних змін носіїв спроможностей та їх комбінації в організаційній структурі військового формування $є$ змістом функціонування різних систем оборонного планування, які прийняті в арміях країн світу.

Для переходу до обгрунтування параметрів розвитку військових формувань ЗС України на основі спроможностей нині обрано стратегію використання готової системи планування розвитку спроможностей однієї з країн-членів НАТО - ЗС США. Вона серед позитивних рис (працездатна, має розвинуту систему обгрунтування, забезпечує високий рівень задоволення потреб ЗС у ресурсах) має також недосяжні на середньо- та короткострокову перспективу для втілення в Україні, а саме:

- вона не пристосована для функціонування в умовах значних ресурсних обмежень;

- орієнтована на розвинутий внутрішній та вихід на зовнішній ринки оборонних технологій та оборонної продукції;

- потребує міцної та чисельної структури обгрунтування, планування та реалізації концепцій, програм i планів (структури науково-дослідних установ, лабораторій, бюро, агенцій, освітньої, цивільної та приватної науки, для вирішення завдань національної безпеки і оборони);

- спирається на відповідні структури НАТО, $\mathrm{EC}$, які за своїми ресурсними та інтелектуальними можливостями значно перевищують можливості України.

За таких умов використання у чистому вигляді цієї системи планування потребує великого обсягу ресурсів і часу для перебудови всіх інститутів, пов'язаних із оборонним плануванням.

На сьогодні для розвитку військових 3С України успішно використовуються окремі процедури планування розвитку спроможностей НАТО, особливо це стосується визначення напрямів розвитку через зміни їх базових компонентів (DOTMLPFI), формування деяких нових документів, що регламентують планування розвитку спроможностей.
Нині планування розвитку спроможностей призупинилось на тому, що використання готової системи планування та окремих процедур планування спроможностей НАТО для розвитку спроможностей військових формувань ЗС України не може швидко дати очікуваного результату, тому перспектива їх втілення не може вважатись доцільною. При тому залишились незавершеними проблемні питання, що стосуються втілення у практику важливих процедур процесу розвитку спроможностей, а саме:

визначення вимог до спроможностей, опис яких нині здійснюється лише якісно, на словах, але кількісних показників їх вимірювання не визначено, оскільки відсутні нормативи. Це призвело до неможливості кількісно визначити наявні спроможності та вимоги до них у процесі їх оцінювання для усунення або мінімізації дефіциту спроможностей;

визначення потреби в ресурсах, їх узгодження 3 можливостями інвесторів та виробників оборонної продукції для планування заходів розвитку;

управління виконанням програм і планів розвитку спроможностей не спирається на моніторинг отриманих результатів, які потребують зміни пріоритетів виконання запланованих заходів та розподілу ресурсів на їх виконання, що, у свою чергу, вимагає наявності відповідальних осіб (менеджерів) відповідних програм, проектів і планів;

встановлення мінімально необхідного переліку документів, що регламентують розвиток спроможностей, оскільки в ході планування значно збільшується кількість документів, особливо проміжних та додаткових, що призводить до затягування часу на розроблення ключових документів: концепцій, програм і планів. Органи управління у наявному складі не в змозі виконати такий обсяг робіт.

Втілення вищезазначених процедур потребує отримання необхідних знань та розуміння природи спроможностей, володіння методологічними основами планування розвитку спроможностей. Це потребує зміни стратегії переходу на планування розвитку спроможностей військових формувань ЗС України, яка б включала загальну методологію, 
визначення процесу як складових процедур, затвердження переліку планувальних документів та формування працездатних структурних підрозділів оборонного планування. Доцільність використання цієї стратегії повинна визначатися витратою ресурсів та часу на їх втілення, що $є$ актуальним питанням в умовах проведення ЗС України операції Об'єднаних сил в окремих східних областях [14; 17].

Одним із основних принципів, які прийняті в оборонному плануванні країн-членів НАТО, є такий, що пропонує максимально використовувати наявні в країні спроможності, досягнення, інструменти і правила для подальшого їх розвитку [15-16]. Виходячи $з$ цього, та за оцінкою переваг і недоліків найбільш доцільною є стратегія побудови системи планування на основі інтеграції різних систем, яка б використовувала кращі процедури процесів розвитку спроможностей НАТО та існуючі процедури розвитку військових формувань ЗС України.

Суть цієї стратегії полягає у максимальному використанні існуючих власних процедур оборонного планування, які $є$ надійними та такими, що достатньо засвоєні фахівцями оборонного планування. При цьому неефективні та непрацездатні процедури оборонного планування 3С України доцільно посилити або змінити тими, що є у розпорядженні країн-членів НАТО. Необхідно зберегти працездатний варіант алгоритму виконання завдань, терміни, перелік документів (основних та проміжних) 3 метою адаптації такої системи до принципів та правил, якими користуються країни-члени НАТО, спеціалісти оборонного планування ЗС України.

Ідентичність та схожість більшості процедур визначення здатності військових формувань виконати поставлені завдання методом виміру спроможностей в НАТО та досягнення визначеного стану боєздатності в ЗС України дозволяє проведення взаємних уточнень або доповнень, вони можуть бути інтегровані одна в одну.

Військове формування у такому разі, з одного боку, має набір спроможностей, необхідних для успішних дій в операції, з другого боку, характеризується станом боєздатності, який дозволяє ефективно виконувати поставлені завдання. Різні властивості військового формування залежать від таких характеристик, як: склад сил; навченість, оснащеність OBT, Мт3, військовою інфраструктурою; укомплектованість особовим складом та кадрами бойових формувань, формувань забезпечення та управління.

Інтеграція двох підходів до визначення здатності виконати поставлені завдання можлива на рівні двох процедур виміру:

здатності виконати типові завдання для визначення дефіциту спроможностей при плануванні заходів їх розвитку; поточного стану боєздатності військового формування в ході виконання поставлених завдань та під час виміру досягнутого стану здатності.

Розуміння природи процесу розвитку військового формування полягає у визначенні в ЗС України системи таких показників, які достатньою мірою можуть служити для розвитку оперативних (бойових та спеціальних) спроможностей військових формувань. Інтеграція двох процедур можлива на рівні використання показників оперативних спроможностей НАТО для їх адаптації до результатів моделювання операцій (бойових дій) з використанням існуючих (українських) моделей. Показники оперативних спроможностей мають однакову природу, а нормативи і стандарти виконання типових завдань мають однотипні просторові, часові, ударні, маневрові та інші показники.

Управління процесом змін характеристик властивостей військових формувань в ході реалізації програм і планів їх розвитку означає визначення більш ефективного та зрозумілого процесу обгрунтування складу військового формування, вимір його здатності виконувати поставлені завдання в ході бойових дій, вибір системи управління здатністю виконувати ці завдання. Інтеграція двох систем у цьому напрямі - це адаптація напрямів, завдань та заходів розвитку військових формувань ЗС України до розвитку базових компонентів (складових) спроможностей НATO (DOTMLPFI).

Інтеграція управління ресурсами для досягнення визначеної здатності військового формування виконати поставлені завдання в операції (бойових діях) полягає у:

виборі більш точного методу визначення потреби в ресурсах на основі фаз життєвого циклу спроможностей або на основі вартості заходів щодо кількісно-якісних змін елементів складу (бойових формувань, формувань оперативного (бойового), логістичного (тилового, технічного), медичного забезпечення, постачання ресурсів, структурних підрозділів управління (воєнно-політичного, адміністративного, безпосереднього управління військами (силами));

виборі такого варіанту розподілу ресурсів, щоб до програм і планів не включати заходи, які не можуть бути забезпечені ресурсами, а також щоб отримати максимальну кількість військових формувань, здатних виконати поставлені завдання на кінець періоду планування або на визначений час.

Вирішення існуючих проблемних питань потребує комплексного підходу до організації переходу на планування розвитку спроможностей військових формувань ЗС України, а саме:

А) У галузі військової освіти: переорієнтувати курс підготовки спеціалістів на планування розвитку спроможностей військових формувань, для чого 
підготувати групу фахівців, які здатні довести цей курс до слухачів. Підготувати посібники, рекомендації основних положень щодо розвитку спроможностей. Іноземних радників використовувати не для донесення загальних положень, а для детального вивчення процедур планування спроможностей.

Б) У галузі теорії і практики побудови та розвитку організаційних структур військових формувань: мати уявлення того, що покладається в основу побудови та розвитку військового формування для отримання необхідних характеристик в операціях, бойових діях. Для цього чітко визначитись із:

характеристиками операцій, бойових дій, відновити практику визначення та розрахунків нормативів для військових формувань;

процесом формування властивостей військового формування шляхом змін ТTХ носіїв та комбінації їх в організаційній структурі стосовно здатності виконати низку бойових та спеціальних завдань в бою, операції.

В) У галузі планування розвитку військових формувань: втілити такі процедури управління оборонними ресурсами, які виключають ручне управління потребами, їх розподілом. Для чого:

втілити метод визначення потреби в ресурсах (не тільки фінансових) на основі вартості фаз життєвого циклу спроможностей або кількісно-якісних змін елементів складу військового формування;

запровадити у практику процедуру узгодження 3 інвесторами та виробниками потреби в ресурсах 3 виділеними на розвиток спроможностей;

здійснювати розподіл ресурсів після узгодження їх 3 можливістю інвесторів та виробників забезпечити постачання продукції у встановлений строк за узгодженими цінами;

виключити випадки включення до програм і планів заходів, які не можуть бути забезпечені ресурсами;

втілити процедуру управління змінами характеристик військових формувань в ході реалізації програм і планів для обов'язкового (гарантованого) досягнення визначеної здатності військового формування виконати поставлені завдання в бою, операції; визначити послідовність виконання процедур обгрунтування вихідних даних для планування розвитку військових формувань, перелік мінімально достатніх планувальних документів [12-13].

Д) У галузі організації:

мати єдність у поглядах на весь процес планування, і на його окремі процедури, діяти за визначеним планом;

відповідати та звітувати за досягнутий результат, з цією метою призначити в Міністерстві оборони України, Генеральному штабі ЗС України командуваннях видів, спеціальних військах, окремих родах військ (сил) 3С України відповідальних осіб за перехід до планування спроможностей:

максимально використовувати те, що вже досягнуто, минулий досвід та минулу наукову школу, не копіювати сліпо процес і процедури в інших країнах-членах НАТО, а брати за основу принципи i правила, які вони використовують, узгоджуючи їх 3 умовами України [13-14; 17].

Реалізація запропонованої стратегії може забезпечити завершення переходу до планування розвитку спроможностей військових формувань ЗС України і не допустити втрати управління цим процесом.

\section{Висновки та перспективи подальших досліджень}

Вирішення проблемних питань щодо визначення вимог до спроможностей, їх кількісного виміру, розрахунку необхідних ресурсів, їх узгодження 3 виділеними для досягнення визначених спроможностей, управління виконанням програм і планів шляхом зміни стратегії переходу дозволяє завершити втілення планування розвитку спроможностей військових формувань ЗС України.

Доцільно вищезазначені рекомендації використати для уточнення існуючих планів з метою вирішення проблемних питань завершення переходу на планування розвитку спроможностей військових формувань 3С України.

\section{Список літератури}

1. Закон України “Про Збройні Сили України” // Відомості Верховної Ради України. - 1992. - № 9. - С. 108.

2. Закон України “Про державні цільові програми” // Відомості Верховної Ради України. - 2004. - № 25. - С. 352.

3. Постанова Кабінету Міністрів України “Про затвердження Порядку розроблення та виконання державних цільових програм” № 106 від 31.01.2007.- 16 с.

4. Рекомендації з оборонного планування на основі спроможностей в Міністерстві оборони України та Збройних Силах України. - Київ: МО України, 2017. - 52 с.

5. Міністр оборони України. Рекомендації з порядку організації проведення оцінювання спроможностей у Збройних Силах України, затв. 07.12.2017. - 27 с.

6. Військовий стандарт ВСТ 01.040 .003 - 2014 (01). Оборонне планування. Державна програма розвитку Збройних Сил України. Порядок розроблення, виконання та звітування: видання офіційне. - Київ: МО України, 2014. - 18 с. 
7. ВСТ 01.040 .001 - 2013 (01). Оборонне планування. План утримання та розвитку Збройних Сил України. Порядок розроблення, виконання та звітування: видання офіційне. - Київ: МО України, 2013. - 11 с.

8. Методичні рекомендації з організації та проведення оборонного огляду. - Київ: МО України, 2019. - 83 с.

9. Наказ Міністерства оборони України. Інструкція про організацію підготовки та проведення інспекційних заходів № 440 від 21.07.2011.

10. Наказ Генерального штабу Збройних Сил України. Інструкція з організації підготовки та проведення перевірок у Збройних Силах України № 6 від 2.01.2020.

11. Наказ Генерального штабу Збройних Сил України. Порядок розроблення (розміщення) стандартів (каталогів завдань) з підготовки та проведення оцінювання за стандартами підготовки Збройних Силах України № 26 від 27.01. 2020 .

12. Методика розподілу оборонного бюджету України між складовими сил оборони з урахуванням показників потреб та пріоритетності завдань цих складових на плановий рік / О.М. Семененко, Р.В. Бойко, О.Г. Водчиць, С.П. Василенко, Г.Г. Зубрицька, О.І. Кремешний //Наука і Техніка Повітряних Сил Збройних Сил України. - 2017. - № 4(29). C. 123-131. https://doi.org/10.30748/nitps.2017.29.17.

13. Дєнєжкін М.М. Вплив оцінювання та аналізу спроможностей на визначення заходів розвитку Збройних Сил України // Збірник наукових праць Харківського національного університету Повітряних Сил. - 2018. - № 3(57). C. 57-64. https://doi.org/10.30748/zhups.2018.57.08.

14. Дєнєжкін М.М. Основні положення оцінювання спроможностей військових формувань під час планування їх розвитку: інф.-аналіт. матер. / М.М. Дєнєжкін, В.П. Дідіченко, С.А. Середюк. - Київ: ЦНДІ ЗС України, 2020. - 123 с. Panel 3 .

15. Guide to Capability-Based Planning. The Technical Cooperation Program Joint Systems and Analysis GroupTechnical

16. Defence Capability Development Handbook 2014. Австралія. Розвиток оборонних спроможностей. Сараbility Development@defence.gov.au.

17. Дєнєжкін М.М. Проблемні питання реформування системи оборонного планування в Збройних Силах України / М.М. Дєнєжкін // Актуальні проблеми проведення оборонної реформи в Україні: зб. матер. міжнарод. наук.-практ. конф. (Київ, 24 бер. 2017 р.). - Київ: НУОУ, 2017. - С. 81-88.

Надійшла до редколегії 02.12.2020 Схвалена до друку 05.01.2021

\section{Відомості про автора:}

Дєнєжкін Микола Миколайович

доктор військових наук старший науковий співробітник

провідний науковий співробітник науково-дослідного управління проблем розвитку Збройних Сил України

Центрального науково-дослідного інституту

Збройних Сил України,

Київ, Україна

https://orcid.org/0000-0003-0918-0880

\section{Information about the author:}

\section{Mykola Dieniezhkin}

Doctor of Military Sciences

Senior Research

Lead Research

of Scientific Research Department of Research Problems of Armed Forces Development of Central

Scientific-Research Institute of Armed Forces of Ukraine, Kyiv, Ukraine

https://orcid.org/0000-0003-0918-0880

\title{
ПУТИ РЕШЕНИЯ ПРОБЛЕМНЫХ ВОПРОСОВ ПЛАНИРОВАНИЯ РАЗВИТИЯ СПОСОБНОСТИ ВЫПОЛНИТЬ ПОСТАВЛЕННЫЕ ЗАДАЧИ ВОИНСКИМИ ФОРМИРОВАННЯМИ ВООРУЖЕННЫХ СИЛ УКРАИНЫ
}

\author{
Н.Н. Денежкин
}

В статье на основе результатов анализа руководящих документов, которые регламентируют перевод системы оборонного планирования на планирование развития Вооруженных Сил Украины (ВС Украины) на основе способности выполнить поставленные задачи, полученного опыта перехода с планирования развития боевых возможностей, боевого состава и его организационной структуры на планирование развития их способности определены проблемные вопросы такого перехода. Сделан вывод о неэффективности выбранной стратегии такого перехода, недостаточности усилий для осуществления методического сопровождения прочесса, его организации, качества полученных результатов. Предложены возможные пути решения проблемных вопросов, которые возникли в процессе перехода на планирование развития способности выполнить поставленные задачи воинских формирований ВС Украины. Определено, что выбранные стратегии использования готовой системы планирования развития способности выполнить поставленные задачи одной из стран-участнии НАТО, использования отдельных фрагментов (отдельных прочедур) планирования способности выполнить поставленные задачи НАТО для развития воинских формирований ВС Украины не эффективны и не могут сегодня решить задачи такого перехода. На основе анализа позитивных и негативных черт, возможных последствий с учетом условий Украины предложена стратегия, которая интегрирует в себе два метода планирования способности выполнить поставленные задачи НАТО и развития боевых возможностей воинских формирований ВС Украины, включает в себя лучшие прочедуры, которые используют страны-члены НАТО, учитывает условия и полученный опыт планирования развития ВС Украины. Вылелены возможные прочедуры для взаимной интеграчии, на которых 
целесообразно осуществить синтез двух систем планирования для обеспечения ее работоспособности в условиях ведения боевых действий Украиной и ограниченного времени.

Ключевые слова: боеспособность, способность выполнить поставленные задачи, норматив, стандарт, типовые задачи, условия выполнения типовых задач.

\section{WAYS OF RESOLVING PROBLEM QUESTIONS FOR PLANNING THE DEVELOPMENT OF UKRAINIAN ARMED FORCES MILITARY FORMATION'S CAPABILITIES}

\section{Dieniezhkin}

Article is about transfering of the defense planning system, based on development of combat capacity of military formations of Armed Forces of Ukraine (AF Ukraine) into development of their capabilities. It is based on results of analysis of guiding documents regulating planning of development AF of Ukraine on the basis of capabilities, experience gained from the transition from combat capacity planning, of combat formations and its organizational structure problematic issues of such a transition. It's made a conclusion about snefficiency of the chosen strategies of such transition, lack of efforts for realization of methodical support of process, its organization, quality of negative results. Possible ways to solve the problematic issues that arose during the transition to planning the development of capabilities of military formations of the AF Ukraine are proposed. It is determined that the chosen strategy of using the ready system of capability development planning of one of the NATO member states, use of fragments (separate procedures) of NATO capability planning for the development of military formations of the AF Ukraine are not effective and cannot solve the problem of such transition. Based on the analysis of positive and negative features, possible consequences taking into account the conditions of Ukraine, the proposed strategy, which integrates both methods of planning the development of military capabilities in NATO and the development of combat capabilities of military formations of the AF Ukraine, includes best procedures used by member countries. NATO, takes into account the conditions and experience gained in planning the AF Ukraine. Possible procedures for mutual integration have been identified, on which it is expedient to carry out the synthesis of two planning systems into a single one to ensure its efficiency in the conditions of hostilities in Ukraine and for a limited time.

Keywords: combat capability, ability, norm, standard, typical tasks, conditions of performance of typical tasks. 